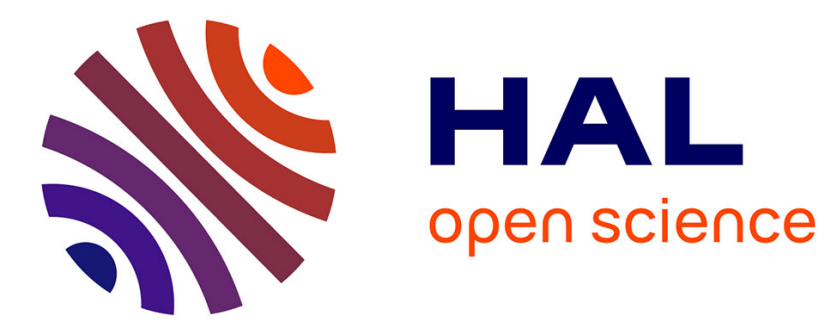

\title{
CVD OF COPPER USING CuCl AS PRECURSOR
}

\author{
C. Lampe-Önnerud, A. Hårsta, U. Jansson
}

\section{To cite this version:}

C. Lampe-Önnerud, A. Hårsta, U. Jansson. CVD OF COPPER USING CuCl AS PRECURSOR. Journal de Physique IV Proceedings, 1991, 02 (C2), pp.C2-881-C2-888. 10.1051/jp4:19912105 . jpa00249783

\section{HAL Id: jpa-00249783 https://hal.science/jpa-00249783}

Submitted on 1 Jan 1991

HAL is a multi-disciplinary open access archive for the deposit and dissemination of scientific research documents, whether they are published or not. The documents may come from teaching and research institutions in France or abroad, or from public or private research centers.
L'archive ouverte pluridisciplinaire HAL, est destinée au dépôt et à la diffusion de documents scientifiques de niveau recherche, publiés ou non, émanant des établissements d'enseignement et de recherche français ou étrangers, des laboratoires publics ou privés. 
Colloque C2, suppl. au Journal de Physique II, Vol 1, septembre 1991

\title{
CVD OF COPPER USING CUCl AS PRECURSOR
}

\author{
C. LAMPE-ÖNNERUD, A. HA็RSTA and U. JANSSON \\ Thin Film and Surface Chemistry Group, Department of \\ Inorganic Chemistry, University of Uppsala, Box 531, S-751 21 \\ Uppsala, Sweden
}

\begin{abstract}
Chemical vapour deposition of copper using $\mathrm{CuCl}$ as the copper precursor has been investigated. It was found that the evaporation of $\mathrm{CuCl}$ from a solid powder was a critical step. The evaporation process was strongly dependent on mainly two factors, deviations from equilibrium upon evaporation and formation of hydroxychloride on the powder surface. The copper deposition was investigated for two different gas mixtures, $\mathrm{Ar} / \mathrm{CuCl}$ and $\mathrm{Ar} / \mathrm{CuCl} / \mathrm{H}_{2}$, and two different substrates, $\mathrm{SiO}_{2}$ and $\mathrm{Si}(111)$. On the $\mathrm{SiO}_{2}$ substrate, elemental $\mathrm{Cu}$ was deposited using an $\mathrm{Ar} / \mathrm{CuCl} / \mathrm{H}_{2}$ vapour. The resistivity of the $\mathrm{Cu}$ film was $3.3 \mu \Omega \cdot \mathrm{cm}$. When $\mathrm{Si}(111)$ substrates were employed, the $\mathrm{Cu}_{3} \mathrm{Si}$ phase was invariably obtained. This phase grew with an epitaxial relationship to the $\mathrm{Si}(111)$ substrate. At lower deposition temperatures or with $\mathrm{H}_{2}$ present in the vapour, elemental $\mathrm{Cu}$ in the form of particles was deposited on the $\mathrm{Cu}_{3} \mathrm{Si}$ layer. A relatively large amount of chlorine was detected on the surface of the $\mathrm{Cu}$ particles.
\end{abstract}

\section{INTRODUCTION}

Copper has recently been considered as a possible interconnect metal in VLSI technology since it offers many attractive properties such as low resistivity and good electromigration resistance. A disadvantage with $\mathrm{Cu}$ is the high reactivity of the metal towards silicon. Cu diffuses easily into silicon forming deep levels in the band gap. Moreover, extensive silicide formation has been reported also at low temperatures $/ 1,2 /$. Thus, it is clear that the use of $\mathrm{Cu}$ as a metallization material requires some kind of inert diffusion barrier between the metal and Si.

Chemical vapour deposition (CVD) is a widely used technique to produce thin films of high quality. However, $\mathrm{CVD}$ of $\mathrm{Cu}$ has only been reported by a few authors. The most commonly used precursors have been various organometallic compounds (see $e$. g., refs. $13-5 /$ ). A major problem with organometallic $\mathrm{Cu} C \mathrm{CVD}$ is that many precursors tend to be unstable. Moreover, several authors have reported that organocopper compounds frequently yield films contaminated with $\mathrm{C}$ and $\mathrm{O}$ (see $e$. g., ref. /4/). An alternative to organometallic $\mathrm{Cu}$ $\mathrm{CVD}$ is to use copper halides as $\mathrm{Cu}$ sources. The copper halides are stable inorganic compounds which can be prepared with a high purity. At room temperature the halides are solids but they exhibit reasonably high vapour pressures also at rather low temperatures suggesting a potential use as precursor materials in $\mathrm{Cu}$ CVD. The use of halides as metal precursors in Cu CVD has not been much investigated. However, the interactions between gaseous, liquid and solid $\mathrm{CuCl}$ and different silicon substrates have been studied by Weber and coworkers in several papers (see $e . g ., / 6,7 /$ ).

In this work we have studied $\mathrm{CVD}$ of $\mathrm{Cu}$ using $\mathrm{CuCl}$ as the $\mathrm{Cu}$ source. Preliminary experiments indicated that the evaporation of $\mathrm{CuCl}$ from the solid powder was a critical step in the process. The first part of this study has therefore been devoted to investigating the evaporation of $\mathrm{CuCl}$ from different solid powders. In a second part, $\mathrm{Cu}$ was deposited on $\mathrm{Si}(111)$ and $\mathrm{SiO}_{2}$ substrates in order to demonstrate the feasibility of using $\mathrm{CuCl}$ as a metal source in $\mathrm{Cu} \mathrm{CVD}$. 


\section{EXPERIMENTAL}

\section{1. Film deposition}

The deposition experiments were carried out in a hot-wall CVD reactor made of quartz. A three-zone furnace was used to obtain a suitable temperature profile of the reactor during the deposition process. In zone I, gaseous $\mathrm{Cu}_{\mathrm{x}} \mathrm{Cl}_{\mathrm{x}}$ species were obtained after evaporation from a powder of $\mathrm{CuCl}$ placed in a quartz boat. The evaporated $\mathrm{Cu}_{\mathrm{x}} \mathrm{Cl}_{\mathrm{x}}$ species were transported by a carrier gas, $\mathrm{Ar}$ or $\mathrm{Ar} / \mathrm{H}_{2}$, through zone II and over the substrate placed in zone III. Zone II was kept at a higher temperature than zone I and was used as a buffer zone to avoid condensation of the gaseous $\mathrm{Cu}_{\mathrm{x}} \mathrm{Cl}_{\mathrm{x}}$ species before reaching the substrate. Prior to an experiment, the powder boat was placed in the reactor tube outside the furnace. The experiment was started by moving the boat by means of a magnet into the evaporation zone.

The CVD system was pumped with a mechanical rotary pump, which maintained a base pressure of about $10^{-3}-10^{-2} \mathrm{~Pa}$. A capacitance manometer was used to monitor the pressure. During the experiments the total pressure in the system was controlled by a needle valve. A cold trap filled with liquid nitrogen was used to reduce the back diffusion of pump oil from the vacuum pump. The leak rate of the system was continuously controlled by the pressure increase technique and found to be better than $3.3 \cdot 10^{-7} \mathrm{~Pa} \cdot \mathrm{m}^{3} / \mathrm{s}\left(2.5 \cdot 10^{-6} \mathrm{Torr} \cdot 1 / \mathrm{s}\right)$. At the total pressure and flow rate used in this investigation, this air leak rate corresponds to an addition of about 2 ppm of impurities (mainly $\mathrm{N}_{2}, \mathrm{O}_{2}$ and $\mathrm{H}_{2} \mathrm{O}$ ) to the reaction gas mixture.

Preliminary experiments indicated that the deposition rate of $\mathrm{Cu}$ was dependent on the $\mathrm{CuCl}$ powder used. The following four different types of $\mathrm{CuCl}$ were tested:

(i) as-delivered, $i$. e., uncleaned $\mathrm{CuCl}$ (Merck, $p . a .>98 \%$ ). This powder exhibited a green colour indicating the presence of $\mathrm{Cu}$ (II).

(ii) $\mathrm{HCl}$-cleaned $\mathrm{CuCl}$ (Merck, p. a. $>98 \%$ ). The powder was cleaned with a 1:10 mixture of conc. $\mathrm{HCl}$ and pure $\mathrm{H}_{2} \mathrm{O}$, then dried with $\mathrm{CH}_{3} \mathrm{OH}$ at $110^{\circ} \mathrm{C}$. The main purpose of the cleaning process was to remove $\mathrm{Cu}(\mathrm{II})$ compounds from the powder surface.

(iii) $99.99 \% \mathrm{CuCl}$ (Aldrich).

(iv) purified $99.99 \% \mathrm{CuCl}$ (Aldrich). The powder was sublimed under vacuum at $430^{\circ} \mathrm{C}$, followed by zone-refining at $440^{\circ} \mathrm{C}$.

All experiments were performed with $\operatorname{Ar}$ (claimed purity $>99.9997 \%$ ) as the carrier gas. In some experiments $\mathrm{H}_{2}$ (>99.9997\%) was added as a reducing agent. We have used two different substrate materials, $\mathrm{SiO}_{2}$ and $\mathrm{Si}$. In order to increase the nucleation rate of $\mathrm{Cu}$, the surface of the $\mathrm{SiO}_{2}$ substrate (Synsil, Westdeutsche Quartzschmelze) was scratched by a grinding paper (grain size $30 \mu \mathrm{m}$ ). Prior to an experiment, the $\mathrm{SiO}_{2}$ substrates were degreased in methanol, etched in $4 \% \mathrm{HF}$, rinsed in water and finally dried with $\mathrm{N}_{2}$ gas. The Si substrates (p-doped $S i(111)$ with a resistivity of $1-5 \Omega \cdot \mathrm{cm}$ ) were boiled for 20 minutes at $95^{\circ} \mathrm{C}$ in a $1: 3$ mixture of $\mathrm{H}_{2} \mathrm{O}_{2}(30 \%)$ and $\mathrm{H}_{2} \mathrm{SO}_{4}$ (conc.). Immediately before an experiment, the substrates were etched in $4 \% \mathrm{HF}$ without subsequent water rinse in order to achieve a hydrophobic and oxide free surface. In this work, the $\mathrm{CuCl}$ was evaporated at 300 and $350^{\circ} \mathrm{C}$. The deposition temperatures ranged from 350 to $500^{\circ} \mathrm{C}$. The deposition time was varied from 1 to 5 hours. The pressure and the linear gas flow velocity were kept constant at $1.3 \mathrm{kPa}(10 \mathrm{Torr})$ and $0.1 \mathrm{~m} / \mathrm{s}$, respectively.

\section{2. Characterization}

The different $\mathrm{CuCl}$ powders were examined by $\mathrm{X}$-ray powder diffraction in a Guinier-Hägg-type focusing camera with $\mathrm{CuK} \alpha_{1}$ radiation. The evaporation rate of $\mathrm{CuCl}$ was determined from weight-loss measurements using a precision balance. The surface area of the powders was estimated from grain-size measurements in an optical microscope.

The thickness of the Cu films was measured by X-ray fluorescence spectroscopy (XRFS), using the intensity of the $\mathrm{CuK} \alpha$ peak. As reference films we used e-beam evaporated $\mathrm{Cu}$ films deposited on glass substrates. The thicknesses of the reference films were determined by a profilometer (Tencor Instruments, Alpha step 200 , claimed accuracy $0.5 \mathrm{~nm}$ ). The deposited films were analyzed with X-ray photoelectron spectroscopy (XPS) and Auger electron spectroscopy (AES) using a PHI 5500 instrument. The XPS analysis were performed with $\mathrm{MgK} \alpha$ radiation (1253.6 eV). The AES spectra were recorded in the direct mode with a $5-10 \mathrm{keV}, 5 \mathrm{nA}$ electron beam, corresponding to a beam diameter of about $1 \mu \mathrm{m}$. Phase analysis of the films was made by X-ray diffractometry (XRD) using a Siemens D5000 diffractometer with CuK $\alpha$ radiation. The morphology was examined in a light optical microscope and in a JEOL-JSM 840 scanning electron microscope (SEM). 


\section{RESULTS AND DISCUSSION}

\section{1. Evaporation of $\mathrm{CuCl}$}

Preliminary experiments with the different $\mathrm{CuCl}$ powders indicated that the deposition process was strongly influenced by the type of powder used as well as on the treatment of the powder prior to an experiment. It was concluded that this behaviour was due to differences in the evaporation kinetics of $\mathrm{CuCl}$ for the various powders. The first part of this work was therefore devoted to a comparison of evaporation rates between various types of $\mathrm{CuCl}$ powders. It was found that the large variations observed in the evaporation rate were due to two factors: (i) deviation from equilibrium upon evaporation and (ii) formation of a hydroxychloride on the surface of the powder.

Thermodynamical calculations show that $\mathrm{Cu}_{3} \mathrm{Cl}_{3}$ and $\mathrm{Cu}_{4} \mathrm{Cl}_{4}$ are the main species formed in the vapour over a solid powder in the temperature range $300^{\circ} \mathrm{C}$ to $500^{\circ} \mathrm{C}$. The equilibrium partial pressure of copper chloride species, $\mathrm{p}_{\mathrm{eq}}$, in the vapour at this temperature is about $1.05 \mathrm{~Pa}\left(\mathrm{p}_{\mathrm{eq}}=\Sigma \mathrm{i} \cdot \mathrm{p}\left(\mathrm{Cu}_{\mathrm{i}} \mathrm{Cl}_{\mathrm{i}}\right), \mathrm{i}=1-5\right)$. However, our results showed that the actual partial pressure of $\mathrm{CuCl}$ during a typical experiment was considerably lower than $\mathrm{p}_{\mathrm{eq}}$ (the experimental $\mathrm{CuCl}$ partial pressures were calculated from weight-loss measurements). Typically, the $\mathrm{CuCl}$ partial pressure ranged from $2 \%$ to $26 \%$ of the equilibrium partial pressure. The large variation in the $\mathrm{CuCl}$ partial pressures could not be related to the claimed purity of the powder. Instead, it was concluded that the $\mathrm{CuCl}$ partial pressure was dependent on the total surface area of the powder used. This means that the $\mathrm{CuCl}$ concentration in the vapour increases with decreasing grain size of the powder. For example, the $\mathrm{HCl}$-cleaned p. a. $\mathrm{CuCl}$ powder, which has an average grain diameter of about $60 \mu \mathrm{m}$, yields more than ten times higher $\mathrm{CuCl}$ partial pressure than a solid rod of the zone-refined $\mathrm{CuCl}$. The 99.99\% $\mathrm{CuCl}$ (grain size: about $300 \mu \mathrm{m}$ ) gives an intermediate $\mathrm{CuCl}$ partial pressure compared to the $\mathrm{HCl}$-cleaned powder and the zone-refined rod, respectively. Moreover, grinding the zone-refined rod to a powder with an average grain diameter of about $300 \mu \mathrm{m}$, increases the $\mathrm{CuCl}$ partial pressure with about $100 \%$. These results reflect the actual evaporation conditions during the experiments. At equilibrium evaporation, the $\mathrm{CuCl}$ partial pressure will be identical to $\mathrm{p}_{\mathrm{eq}}$ irrespective of the experimental conditions. However, at non-equilibrium evaporation, the evaporation rate (and hence the $\mathrm{CuCl}$ partial pressure) will be influenced by experimental parameters such as the total area of the powder exposed to the carrier gas. As a consequence, several other factors affecting the total area may also influence the $\mathrm{CuCl}$ partial pressure. Examples of such factors are: amount of powder used, sintering of the powder and variations in powder packing. We also found that an increase of the $\mathrm{CuCl}$ powder amount from $0.5 \mathrm{~g}$ to $2.0 \mathrm{~g}$ yielded $100 \%$ higher $\mathrm{CuCl}$ partial pressure in the vapour. However, no experiments have been made to investigate the influence of sintering and powder packing on the evaporation rates.

Another problem with $\mathrm{CuCl}$ as the copper source is its chemical reactivity. $\mathrm{CuCl}$ is a hygroscopic compound and reacts in air with water under the formation of a hydroxychloride, $\mathrm{Cu}(\mathrm{OH}) \mathrm{Cl}$. The formation of this phase results in a colour change of the $\mathrm{CuCl}$ powder from white (or transparent) to green. $\mathrm{XRD}$ analysis of $\mathrm{CuCl}$ powders stored in air shows that large amounts of $\mathrm{Cu}(\mathrm{OH}) \mathrm{Cl}$ are formed on the surface of the grains within a few days. When the $\mathrm{Cu}(\mathrm{OH}) \mathrm{Cl}$ phase is heated, water is removed and an oxychloride phase is formed according to the reaction:

$$
2 \mathrm{Cu}(\mathrm{OH}) \mathrm{Cl}(\mathrm{s}) \rightarrow \mathrm{H}_{2} \mathrm{O}(\mathrm{g})+\mathrm{Cu}_{2} \mathrm{OCl}_{2} \text { (s) }
$$

When stored in air $\mathrm{Cu}_{2} \mathrm{OCl}_{2}$ takes up water and again forms $\mathrm{Cu}(\mathrm{OH}) \mathrm{Cl}$. Thus, the reaction is reversible. It is quite clear that the formation of surface compounds on the $\mathrm{CuCl}$ grains should affect the evaporation rate. We found that a $0.6 \mu \mathrm{m}$ thin $\mathrm{Cu}(\mathrm{OH}) \mathrm{Cl}$ layer reduced the evaporation rate of $\mathrm{CuCl}$ with about a factor of five compared to a powder with a clean surface. $\mathrm{Cu}(\mathrm{OH}) \mathrm{Cl}$ is also formed when the powder is stored in a desiccator and/or in a simple glovebox under $\mathrm{N}_{2}$ atmosphere. After a few weeks storage time, a small colour change to light green can be observed on the surface of an initially clean powder. It was also observed that the evaporation rate of $\mathrm{CuCl}$ from a clean powder decreases with storage time after cleaning. A powder stored for 48 hours yielded an evaporation rate of only about one-third compared to a freshly cleaned powder. Although no $\mathrm{Cu}(\mathrm{OH}) \mathrm{Cl}$ could be directly observed on the surface of the $\mathrm{CuCl}$ grains, it is likely that the formation of this phase is the main reason for the reduced evaporation rates. Moreover, storage of clean powders in a desiccator yields a poor reproducibility of the $\mathrm{CuCl}$ evaporation. The evaporation rate of $\mathrm{CuCl}$ may differ with as much as $50 \%$ between different experiments. It is likely that this is due to small variations in thickness of the $\mathrm{Cu}(\mathrm{OH}) \mathrm{Cl}$ layer. The thickness of the layer is dependent on the storage time in the 
desiccator and, accordingly, large variations in evaporation rate are observed. In contrast, a fair reproducibility $(<10 \%)$ is obtained when $\mathrm{CuCl}$ is evaporated from a powder with a thicker, well-defined layer of $\mathrm{Cu}_{2} \mathrm{OCl}_{2}$ on the surface of the grains.

The results above clearly show that a reproducible $\mathrm{CuCl}$ deposition only could be obtained by proper handling of the powder. The following experimental procedure was therefore used in order to optimize the reproducibility of the $\mathrm{CuCl}$ evaporation: An uncleaned p. a. $\mathrm{CuCl}$ powder (Merck, claimed purity $>98 \%$ ) was chosen. This powder has the smallest grain size of the various powders tested (average grain diameter: about $60 \mu \mathrm{m}$ ) and should, therefore, yield a high evaporation rate. The powder exhibited a light-green colour indicating the presence of $\mathrm{Cu}(\mathrm{OH}) \mathrm{Cl}$. Prior to an experiment, $2 \mathrm{~g}$ of the powder was heat-treated for 45 minutes at $300^{\circ} \mathrm{C}$ in the three zone-furnace. The purpose of the heat-treatment was to remove water from the $\mathrm{Cu}(\mathrm{OH}) \mathrm{Cl}$ phase and form $\mathrm{a} \mathrm{Cu} \mathrm{CCl}_{2}$ phase with a well-defined thickness. The powder was then allowed to cool down during 30 minutes under an Ar atmosphere. Immediately after the powder cleaning, the reactor was filled with Ar up to atmospheric pressure, a substrate was loaded into the reactor, and a deposition experiment was performed. Evaporation from a $\mathrm{CuCl}$ powder with a surface layer of $\mathrm{Cu}_{2} \mathrm{OCl}_{2}$ yielded a higher reproducibility $(<10 \%)$ than by using a clean $\mathrm{CuCl}$ powder. The remaining oxychloride phase does not seem to add any oxygen-containing species to the vapour. XRD of the powder showed that the ratio between $\mathrm{Cu}_{2} \mathrm{OCl}_{2}$ and $\mathrm{CuCl}$ is constant irrespective of evaporation time. Hence, it can be concluded that the $\mathrm{Cu}_{2} \mathrm{OCl}_{2}$ phase is stable and that the evaporation probably takes place after diffusion of $\mathrm{CuCl}$ through the oxychloride layer.

\section{2. Deposition of copper}

The utilisation of $\mathrm{CuCl}$ as precursor in $\mathrm{CVD}$ of $\mathrm{Cu}$ was investigated for two substrates, $\mathrm{SiO}_{2}$ and $\mathrm{Si}(111)$. Various gas mixture compositions were used for the two substrate materials. For deposition on $\mathrm{SiO}_{2}$ substrates, $\mathrm{H}_{2}$ was always added to the carrier gas as a reducing agent. $\mathrm{H}_{2}$ was also used as reducing agent in some of the experiments with $\mathrm{Si}(111)$ substrates. However, silicon is a very reactive material towards most metal halides including $\mathrm{CuCl}$. This means that silicon itself can be used as reducing agent in $\mathrm{Cu} C V D$. Several experiments were therefore performed with only $\mathrm{Ar}$ as a carrier gas in order to evaluate the $\mathrm{Si}$ reduction process.

\subsection{Deposition on $\mathrm{SiO}_{2}$ substrates}

Fig. 1 shows a SEM micrograph of a thin $\mathrm{Cu}$ film deposited on $\mathrm{SiO}_{2}$ substrate. The evaporation temperature and deposition temperature used were $350^{\circ} \mathrm{C}$ and $500^{\circ} \mathrm{C}$, respectively. From the weight-loss of the powder, the partial pressure of $\mathrm{CuCl}$ in the vapour phase was calculated to $1.2 \mathrm{~Pa}$ (for $2 \mathrm{~g}$ of powder). The $\mathrm{H}_{2} / \mathrm{Ar}$ ratio in the carrier gas and the deposition time were $1 / 1$ and 5 hours, respectively.

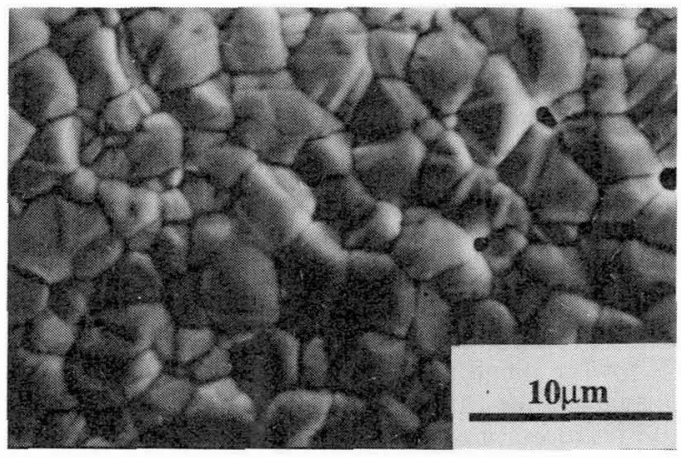

Fig. 1. Top view of a $\mathrm{Cu}$ film deposited on $\mathrm{SiO}_{2}$ at $500^{\circ} \mathrm{C}$. Reaction gas mixture $\mathrm{Ar} / \mathrm{CuCl} / \mathrm{H}_{2}$. 
XRFS analysis of the film showed some thickness variations over the substrate surface. The average thickness of the film was about $1.5 \mu \mathrm{m}$, which corresponds to a deposition rate of about $0.3 \mu \mathrm{m} / \mathrm{h}$. The size of the $\mathrm{Cu}$ grains varies from less than $1 \mu \mathrm{m}$ up to about $5 \mu \mathrm{m}$. It can also be seen that the film contains a small number of pores. Phase-analysis of the film by X-ray diffractometry only showed peaks from copper. From the absence of silicide peaks, it can be concluded that no significant interaction between $\mathrm{Cu}$ and the $\mathrm{SiO}_{2}$ substrate occurs at $500^{\circ} \mathrm{C}$. XPS and AES analyses showed that the bulk of the $\mathrm{Cu}$ film was very pure. No contaminants such as $\mathrm{C}, \mathrm{O}$ or $\mathrm{Cl}$ were detected in the bulk after 30 seconds argon-ion sputtering. However, analyses of the as-deposited film without sputtering revealed the presence of small amounts of $\mathrm{Cl}$ on the surface in addition to $\mathrm{O}$ and $\mathrm{C}$. The oxygen and carbon can be explained by contamination during transport in the air, while the chlorine originates from the deposition process.

The resistivity of the $\mathrm{Cu}$ film was $3.3 \mu \Omega \cdot \mathrm{cm}$. This value is somewhat higher than the generally accepted bulk resistivity $(1.7 \mu \Omega \cdot \mathrm{cm})$. No significant improvement in resistivity was obtained after annealing at $550^{\circ} \mathrm{C}$ for 3 hours.

\subsubsection{Deposition on $\mathrm{Si}(111)$ substrates without $\mathrm{H}_{2}$ in the vapour}

A series of experiment was performed to investigate the deposition of $\mathrm{Cu}$ on $\mathrm{Si}(111)$ without any $\mathrm{H}_{2}$ in the vapour. These experiments were performed at deposition temperatures ranging from $350^{\circ} \mathrm{C}$ to $500^{\circ} \mathrm{C}$. Preliminary experiments showed that the best results were obtained with an evaporation temperature of $300^{\circ} \mathrm{C}$. This temperature yields a $\mathrm{CuCl}$ partial pressure of $0.09 \mathrm{~Pa}$ (for $2 \mathrm{~g}$ of powder). The deposition time was kept constant to one hour in all experiments.

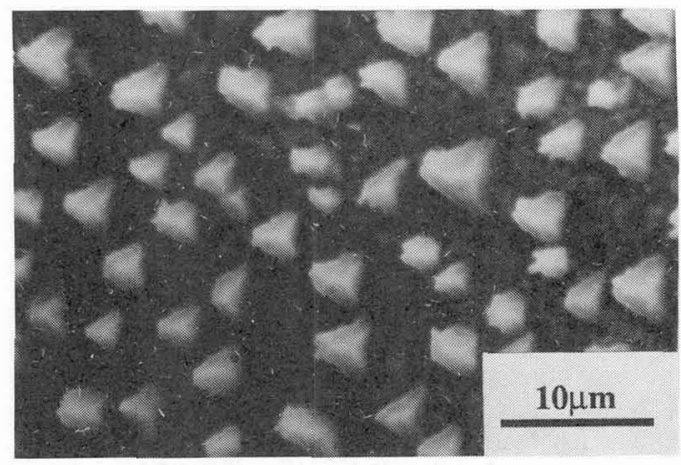

Fig. 2. Top view of a $\mathrm{Cu}_{3} \mathrm{Si}$ film deposited on $\mathrm{Si}(111)$ at $500^{\circ} \mathrm{C}$. Reaction gas mixture $\mathrm{Ar} / \mathrm{CuCl}$.

Fig. 2 shows a typical morphology of a film deposited at $500^{\circ} \mathrm{C}$. The film consists of a very fine-grained bottom layer, acting as a seed layer for larger nuclei. The larger nuclei frequently exhibit a triangular shape. Analyses with XRFS, AES and XPS show that copper has been deposited. However, the X-ray diffraction analysis reveals that no elemental $\mathrm{Cu}$ has been formed at this deposition temperature. The diffractogram shows peaks at $2.438,1.830,1.465$ and $1.221 \AA$, respectively, which can be assigned to $\mathrm{Cu}_{3} \mathrm{Si}$ (for a more extensive discussion of the peak assignment, see ref. /8/). The formation of $\mathrm{A} \mathrm{Cu}_{3} \mathrm{Si}$ phase on the $\mathrm{Si}(111)$ substrate is in agreement with most recent thin film investigations in the Cu-Si system (see $e . g ., / 2,9,10 /$ ). Moreover, all peaks observed in the diffractogram can be identified as reflections of the (001)-type /8/. The observation of only (001) reflexions suggests an epitaxial growth of this phase on the Si(111) substrate. Also this result is in agreement with results obtained by other authors (see $e . g ., / 10-12 /$ ). A proposal for the structural relationship between $\mathrm{Cu}_{3} \mathrm{Si}$ and $\mathrm{Si}(111)$ has recently been presented by Bai and coworkers $/ 10 \%$. For the epitaxial relationship $\mathrm{Cu}_{3} \mathrm{Si}(001) / \mathrm{Si}(111)$ they reported a lattice misfit of about $5 \%$. 
A decrease of the deposition temperature from $500^{\circ} \mathrm{C}$ to $450^{\circ} \mathrm{C}$ had a major impact on the phase content, the chemical composition and the morphology of the films (see Fig. 3). At this deposition temperature, no triangular $\mathrm{Cu}_{3} \mathrm{Si}$ nuclei were formed. Moreover, in the diffractogram additional weak peaks are observed at $d$-values of 2.024 and $2.005 \AA$. The two peaks can be identified as the (301) and (119) reflexions of $\mathrm{Cu}_{3} \mathrm{Si}$. The observation of reflexions other than of the (001)-type suggests a less perfect epitaxial growth. This conclusion is also supported by the less well-ordered morphology (cf. Figs. 2 and 3). However, the high intensities of the (001)-type reflexions indicate that a strong [001]-texture still prevails.

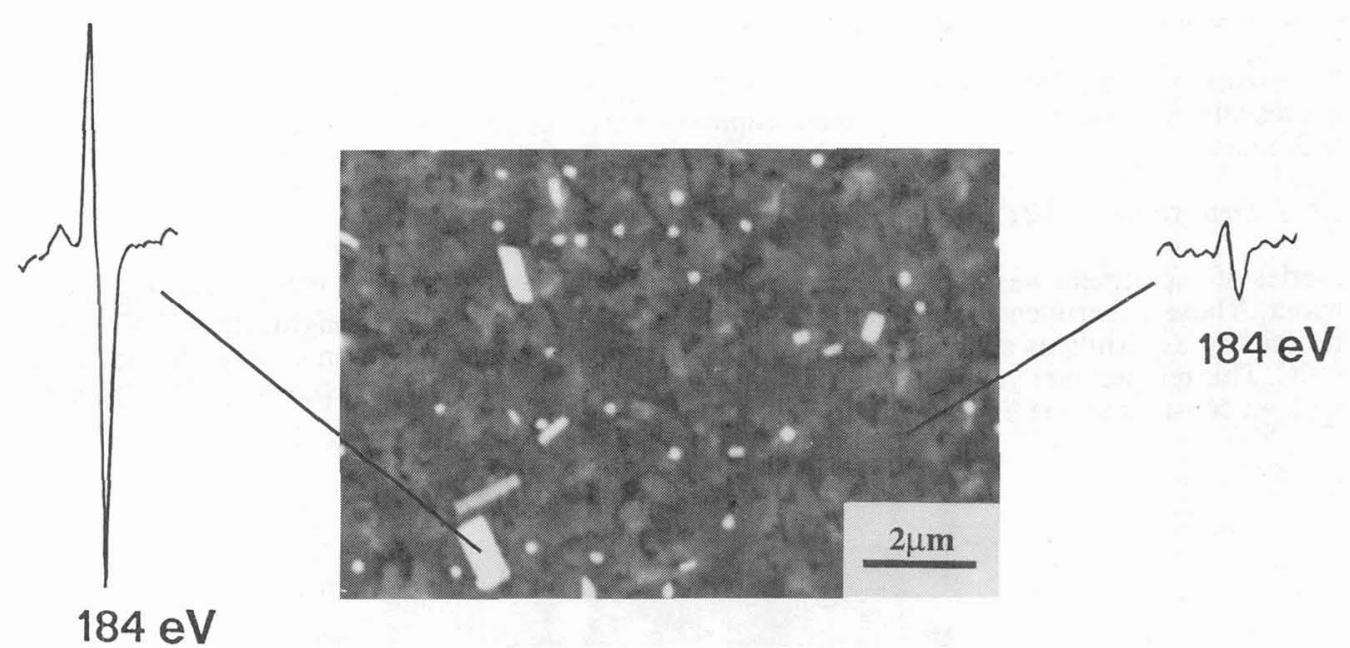

Fig. 3. Top view of a $\mathrm{Cu}_{3} \mathrm{Si} / \mathrm{Cu}$ film deposited on $\mathrm{Si}(111)$ at $450^{\circ} \mathrm{C}$. Reaction gas mixture $\mathrm{Ar} / \mathrm{CuCl}$. The AES spectra of the chlorine LMM peak are shown for $\mathrm{Cu}_{3} \mathrm{Si}$ (right) and $\mathrm{Cu}$ (left).

In addition to the $\mathrm{Cu}_{3} \mathrm{Si}$ phase, elemental $\mathrm{Cu}$ was detected in the films deposited at $450^{\circ} \mathrm{C}$. The $\mathrm{Cu}$ crystals usually exhibited a rectangular shape and ranged in size from $0.3-10 \mu \mathrm{m}$ (see Fig. 3). The AES analysis of the $\mathrm{Cu}$ particles showed that they consisted of pure $\mathrm{Cu}$ with probably small amounts of dissolved Si. An interesting observation was that the surface of the $\mathrm{Cu}$ particles contained rather high amounts of chlorine (approximately 10-20 at\% estimated from elemental standards). In contrast, only very small amounts of $\mathrm{Cl}$ were detected in the surrounding $\mathrm{Cu}_{3} \mathrm{Si}$ film (see Fig. 3). It can also be concluded that $\mathrm{Cl}$ is localized at the surface of the $\mathrm{Cu}$ particles since no $\mathrm{Cl}$ was observed in spectra recorded after 30 seconds of sputtering. The presence of rather high amounts of $\mathrm{Cl}$ on the $\mathrm{Cu}$ particles indicates that the desorption of chlorine-containing species from the surface may play an important role in the deposition of elemental $\mathrm{Cu}$ from a $\mathrm{CuCl}$ precursor.

A further reduction of the deposition temperature from $450^{\circ} \mathrm{C}$ to $350^{\circ} \mathrm{C}$ increases the amount of elemental $\mathrm{Cu}$ formed on the $\mathrm{Si}(111)$ substrate. However, $\mathrm{Cu}$ is still deposited as small particles without forming a completely intact film. The formation of more $\mathrm{Cu}$ at lower deposition temperatures is reasonable, since at higher temperature the diffusion becomes effective enough for complete transformation of deposited $\mathrm{Cu}$ to $\mathrm{Cu}_{3} \mathrm{Si}$. No quantitative $\mathrm{XRD}$ analysis was made to estimate the relative amounts of elemental $\mathrm{Cu}$ and $\mathrm{Cu}_{3} \mathrm{Si}$ formed at different deposition temperatures. However, the XRD diffractograms as well as the SEM micrographs suggest that $\mathrm{Cu}_{3} \mathrm{Si}$ was the majority phase at all deposition temperatures.

The total deposition rate of $\mathrm{Cu}$ (determined by XRFS) defined as the $\mathrm{Cu}$ present in both $\mathrm{Cu}$ and $\mathrm{Cu}_{3} \mathrm{Si}$ varied between $0.025-0.1 \mathrm{mgh}^{-1} \mathrm{~cm}^{-2}$ as the deposition temperature was increased from $350^{\circ} \mathrm{C}$ and $500^{\circ} \mathrm{C}$. These deposition rates correspond to the formation of elemental $\mathrm{Cu}$ films with thicknesses between 300 and 1000 $\AA$. The total deposition rate of $\mathrm{Cu}$ as well as the relative amount of elemental $\mathrm{Cu}$ deposited on the substrate could be increased by increasing the evaporation temperature of $\mathrm{CuCl}$. For example, an increase of the evaporation temperature from $300^{\circ} \mathrm{C}$ to $375^{\circ} \mathrm{C}$ yielded a 35 times higher $\mathrm{CuCl}$ partial pressure in the vapour. 
Films deposited at these partial pressures exhibited a copper-coloured surface suggesting the formation of a more or less intact elemental $\mathrm{Cu}$ film. However, the adhesion of these films was very poor and they peeled off when the samples were removed from the reactor.

Finally, it should be noted that the deposited $\mathrm{Cu}_{3} \mathrm{Si}$ films are unstable in air. Initially, the $\mathrm{Cu}_{3} \mathrm{Si}$ films exhibit a grey-metallic lustre. In a few days in air, the colour of the films start to change into a darker red-brownish shade. The change of colour is due to decomposition of $\mathrm{Cu}_{3} \mathrm{Si}$ into $\mathrm{SiO}_{2}$ and $\mathrm{Cu} / \mathrm{Cu}_{2} \mathrm{O}$ when the films are exposed to air. This transformation is well-known in the literature (see $e . g .$, refs. $/ 9,13 /$ ) and was also confirmed in this study by XRD analysis of films stored in air.

\subsubsection{Deposition on $\mathrm{Si}(111)$ substrates with $\mathrm{H}_{2}$ in the vapour}

A series of experiments were also performed with $\mathrm{H}_{2}$ in the vapour as a reducing agent. The partial pressure of $\mathrm{H}_{2}$ in these experiments were $0.65 \mathrm{kPa}$. Otherwise, the experimental conditions were identical to those used in section 3.2. 1 .

For the samples deposited with $\mathrm{H}_{2}$ in the reaction gas mixture, the phase analytical results were very similar to those obtained without $\mathrm{H}_{2}$. The $\mathrm{Cu}_{3} \mathrm{Si}$ phase is invariably formed at all temperatures and again has a pronounced [001]-texture. For samples deposited at $500^{\circ} \mathrm{C}$, only (001)-type reflexions were observed suggesting epitaxial growth of the silicide phase. The main difference to the results obtained without $\mathrm{H}_{2}$ in the reaction gas mixture, is that elemental $\mathrm{Cu}$ was obtained at all temperatures using $\mathrm{H}_{2}$ in the vapour. It was deposited as small particles but did not form an intact layer. As for the films deposited without $\mathrm{H}_{2}$, the presence of $\mathrm{Cl}$ on the surface of the film was detected by XPS and AES analyses. However, the small size of the $\mathrm{Cu}$ particles made it impossible to determine whether $\mathrm{Cl}$ mainly was localised on these particles or not. No significant difference in $\mathrm{Cl}$ concentration was observed on samples deposited with or without $\mathrm{H}_{2}$.

A major problem by using $\mathrm{H}_{2}$ as a reducing agent was that copper deposition occurred on the reactor walls. This deposition reaction causes a depletion of $\mathrm{CuCl}$ from the reaction gas mixture. The deposition of copper was observed to take place in a broad zone. The position of the zone was dependent on several experimental parameters, such as the temperature profile of the furnace, the gas flow velocity, the $\mathrm{CuCl}$ partial pressure, etc. In our experiments, the position of the zone, and consequently the degree of $\mathrm{CuCl}$ depletion, varied depending on the deposition temperature. The $\mathrm{Cu}$ deposition rate could thus not be determined to any degree of accuracy.

\section{SUMMARY AND CONCLUDING REMARKS}

Chemical vapour deposition of copper using $\mathrm{CuCl}$ as the copper source has been investigated. The study is divided in two parts. The evaporation of $\mathrm{CuCl}$ from different solid powders is first investigated and the deposition process is subsequently evaluated. Two different reaction gas mixtures, $\mathrm{Ar} / \mathrm{CuCl}$ and $\mathrm{Ar} / \mathrm{CuCl} / \mathrm{H}_{2}$ and two different substrate conditions; $\mathrm{SiO}_{2}$ and $\mathrm{Si}(111)$ have been employed. The most important results are:

The evaporation of $\mathrm{CuCl}$ is a critical step in $\mathrm{CVD}$ of $\mathrm{Cu}$ from a solid $\mathrm{CuCl}$ source. The evaporation rate was found to vary between different $\mathrm{CuCl}$ powders and was mainly influenced by two factors, the deviation from equilibrium upon evaporation and the formation of hydroxychloride on the powder surface. Non-equilibrium evaporation indicates that the evaporation is dependent on $e . g$., the total surface area exposed to the carrier gas. The amount of hydroxychloride formed was dependent on $e . g$., the storage conditions of the $\mathrm{CuCl}$ powder.

Elemental $\mathrm{Cu}$ films were deposited on $\mathrm{SiO}_{2}$ substrates using an $\mathrm{Ar} / \mathrm{CuCl}$ reaction gas mixture. The bulk of the copper film was very pure, but small amounts of chlorine were detected on the surface. The resistivity of the $\mathrm{Cu}$ film was found to be $3.3 \mu \Omega \cdot \mathrm{cm}$, which is somewhat higher than the bulk value.

For the $\mathrm{Si}(111)$ substrate and with an $\mathrm{Ar} / \mathrm{CuCl}$ reaction gas mixture, only the $\mathrm{Cu}_{3} \mathrm{Si}$ phase was formed at a deposition temperature of $500^{\circ} \mathrm{C}$. This phase grew with an epitaxial relationship to the $\mathrm{Si}(111)$ substrate, since only (001)-type reflexions were present. When the deposition temperature was lowered, additional weak $\mathrm{Cu}_{3} \mathrm{Si}$ reflexions appeared. However, a strong [001]-texture still prevailed. Furthermore, at lower deposition temperatures elemental $\mathrm{Cu}$ in the form of particles was also present on the surface of the $\mathrm{Cu}_{3} \mathrm{Si}$ layer. The surface of the copper particles contained rather large amounts of chlorine, 
indicating that desorption of chlorine may play an important role in the deposition process. It can finally be noted that the deposited $\mathrm{Cu}_{3} \mathrm{Si}$ films were unstable in ambient atmosphere. When exposed to air, they were found to decompose to $\mathrm{Cu} / \mathrm{Cu}_{2} \mathrm{O}$ and $\mathrm{SiO}_{2}$.

For the $\mathrm{Si}(111)$ substrate and with an $\mathrm{Ar} / \mathrm{CuCl} / \mathrm{H}_{2}$ reaction gas mixture, the results were very similar to the results obtained without $\mathrm{H}_{2}$. The major difference compared to the $\mathrm{Ar} / \mathrm{CuCl}$ vapour was that elemental $\mathrm{Cu}$ was present at all deposition temperatures. The size of the $\mathrm{Cu}$ particles was, furthermore, found to be smaller. It can thus not be determined if chlorine is localised to these particles or not.

From the results of the deposition experiments, it is evident that the $\mathrm{Cu}_{3} \mathrm{Si}$ phase is invariably formed when silicon substrates are used. If $\mathrm{Cu}$ is to be used in VLSI technology, the interaction between $\mathrm{Cu}$ and $\mathrm{Si}$ leading to the formation of the $\mathrm{Cu}_{3} \mathrm{Si}$ phase must be prevented. The $\mathrm{Cu}_{3} \mathrm{Si}$ phase has a much higher resistivity than elemental copper and, furthermore, decomposes in air. In agreement with many previous observations, some kind of diffusion barrier is therefore needed.

\section{ACKNOWLEDGEMENTS}

Financial support from the Swedish Natural Science Research Council and the Swedish Board for Technical Development is gratefully acknowledged. Thanks are also due to Prof. J. - O. Carlsson for valuable comments on the manuscript.

\section{REFERENCES}

11 G. Rossi and I. Landau, Phys. Rev. B 28 (1983) 3597.

12/ L. Stolt and F. M. d'Heurle, Thin Solid Films 189 (1990) 269.

13/ F. A. Houle, C. R. Jones, T. H. Baum, C. Pico and C. A. Kovac, Appl. Phys. Lett. 46 (1985) 204.

14/ M. J. Hampden-Smith, T. T. Kodas, M. Paffett, J. D. Farr and H. -K. Shin, Adv. Mater. 2 (1990) 636.

15/ D. B. Beach, F. L. LeGoues and C. -K. Hu, Chem. Mater. 2 (1990) 217.

/6/ G. Weber, B. Gillot and P. Barret, Phys. Stat. Sol. (a) 75 (1983) 567.

77/ G. Weber, N. Gourgouillon, B. Gillot and P. Barret, Reactivity of Solids 3 (1987) 127.

18/ C. Lampe-Önnerud, U. Jansson, A. Hărsta and J. -O. Carlsson, to be published.

19/ M. Setton, J. van der Spiegel and B. Rothman, Appl. Phys. Lett. 57 (1990) 357.

/10/ P. Bai, G. -R. Yang, T. -M. Lu and D. B. Knorr, J. Mater. Res. 5 (1990) 989.

/11/ J. K. Solberg, Acta Crystallogr. A 34 (1978) 684.

/12/ E. Daugy, P. Mathiez, F. Salvan and J. M. Layet, Surf. Sci. 154 (1985) 267.

/13/ W. F. Banholzer and M. C. Burrell, Surf. Sci. 176 (1986) 125. 